University of Nebraska - Lincoln

DigitalCommons@University of Nebraska - Lincoln

Agronomy \& Horticulture -- Faculty Publications

Agronomy and Horticulture Department

7-1958

\title{
Classification of Root Systems of Forbs of Grassland and a Consideration of Their Significance
}

J. E. Weaver

University of Nebraska-Lincoln

Follow this and additional works at: https://digitalcommons.unl.edu/agronomyfacpub

Part of the Plant Sciences Commons

Weaver, J. E., "Classification of Root Systems of Forbs of Grassland and a Consideration of Their Significance" (1958). Agronomy \& Horticulture -- Faculty Publications. 483.

https://digitalcommons.unl.edu/agronomyfacpub/483

This Article is brought to you for free and open access by the Agronomy and Horticulture Department at DigitalCommons@University of Nebraska - Lincoln. It has been accepted for inclusion in Agronomy \& Horticulture -Faculty Publications by an authorized administrator of DigitalCommons@University of Nebraska - Lincoln. 


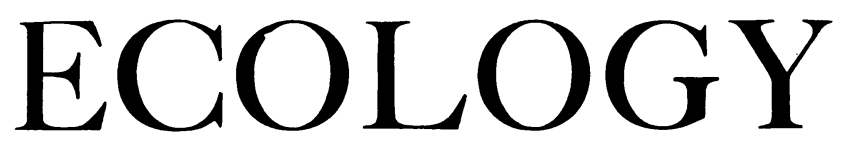

VoL. 39

JULY, 1958

No. 3

\title{
CLASSIFICATION OF ROOT SYSTEMS OF FORBS OF GRASSLAND AND A CONSIDERATION OF THEIR SIGNIFICANCE
}

\author{
J. E. Weaver \\ Department of Botany, University of Nebraska, Lincoln
}

Plants other than grasses constitute an important part of the native grasslands of North America. Most of these are forbs, a few are shrubs and half-shrubs. Probably 85 to 90 percent of the forbs are perennial and most are as deeply rooted and many far more deeply rooted than the grasses. Their number varies considerably from place to place. In the prairie of the central part of the North American Lowland and on the hard lands and sandy soils of the Great Plains they compose, perhaps, between 5 and 15 percent of the vegetation. They are least abundant in the drier habitats.

A recent summary of the community root habits of grasses and an interpretation of the findings included a discussion of soils and climate of each of these extensive areas (Weaver 1958). Hence this need not be repeated here. Suffice it to say that in mixed prairie westward the drier air and decreased water content of soil become limiting factors for growth. Forbs decrease gradually in number, size of individuals, and in the extent of their groupings in societies. This condition prevails clespite the fact that the more mesic species of prairie are largely replaced by more xerophytic ones of the Great Plains.

Forbs accommodate themselves not only to the climate but also to the environment imposed upon them by the grasses. On lowland prairie most forbs are tall. They grow even more rapidly than the grasses and may for a long time or continuously overtop them. Many other species flourish on upland true prairie where they form extensive societies. Much competition occurs between grasses and forbs, not only for light but also for water and nutrients. Roots of most grasses occupy only the first 4 to 6 feet of soil. Usually forbs are more deeply rooted. Their roots have rates of growth not unlike those of grasses and depths of 3 to more than 4 feet may be attained during the first growing season and 8 to 15 feet at ma- turity. Hence, they may absorb partly below the root zone of grasses and thus lessen root competition. Perhaps 90 percent of the abundant forbs, like most prairie grasses, are not only perennial but have a life span extending over a long period of years.

The root habits of a large number of species of forbs have been examined during a period of several years throughout a wide territory from western Iowa, through Nebraska and Kansas, to the mountains of Colorado. Nearly all of the root systems studied were those of mature perennial plants, undisturbed by grazing. Nearly always 3 to 8 plants of a species were examined. Drawings were made simultaneously with the excavating of the roots and always to exact measurements. In the drawings the roots were arranged as nearly as possible in their natural position in a vertical plane. At each examination the work extended over a field sufficiently large, sometimes several square miles in extent, so that the effects of any local differences in soil texture or structure were largely eliminated.

\section{Groups of Forbs Based upon the Nature of Their Root Systems}

An examination of results shows that the root patterns fall naturally into rather distinct groups. This grouping clarifies a confusion of details and furnishes a logical basis for considering the general root development in relation to the environment as modified by the presence of extensive stands of competing grasses.

\section{Group I}

Plants in the first group are characterized by a taproot with widely spreading branches which arise mostly in the first three feet of soil and penetrate deeply. There is relatively little or no provision for much absorption in the surface foot 


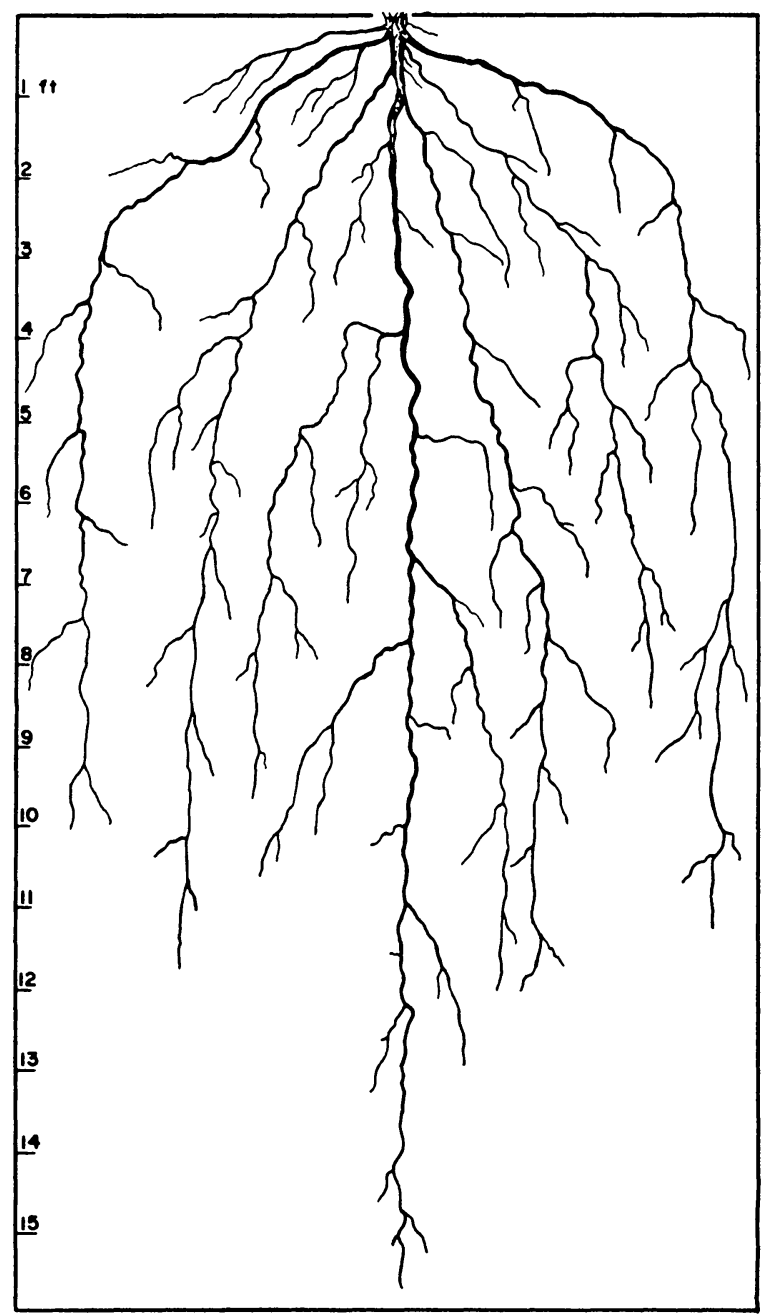

FIG. 1. Root system of blazing star (Liatris punctata).

of soil. This root type is well exemplified by blazing star (Liatris punctata) ${ }^{1}$ in Figure 1.

Table I shows the depth, lateral spread, and general distribution of the species in group I. Column 1 gives the usual depth of penetration in feet; column 2 shows the lateral spread (the radial distance to which roots spread from the base of the plant); and the letters indicate their general distribution in true prairie $(\mathrm{P})$, mixed-prairie hard lands $(M)$, or mixed-prairie sand $(S)$.

The last species in Table I requires explanation. The greatly enlarged taproot of bush morningglory is often 12 or more inches in diameter in the second and third foot of soil. More slender taproots, 3 to 5 inches thick, may maintain their width to 4 feet. At depths of 4 to 5 feet the taproot often breaks up into a large number of deeply penetrating branches. Lateral spread of branch

${ }^{1}$ Nomenclature of forbs follows Gleason's New Britton and Brown Illustrated Flora (1952) or Harrington's Manual of the Plants of Colorado (1954).
TABLE I. Depth and lateral spread in feet and general distribution of species in group I. (See text for explana.tion of symbols in last column)

\begin{tabular}{|c|c|c|c|}
\hline $\begin{array}{l}\text { 1. Argemone platyceras...... } \\
\text { Prickly poppy } \\
\text { 2. Astragalus crassicarpus... } \\
\text { Ground plum } \\
\text { 3. Astragalus drummondi.... } \\
\text { Drummond vetch } \\
\text { 4. Astragalus gracilis....... } \\
\text { Slender loco } \\
\text { 5. Eriogonum microthecum... } \\
\text { Slenderbush eriogonum } \\
\text { 6. Glycyrrhiza lepidota...... } \\
\text { Licorice } \\
\text { 7. Haplopappus spinulosus. } \\
\text { Cut-leaved goldenweed } \\
\text { 8. Kuhnia eupatorioides..... } \\
\text { False boneset } \\
\text { 9. Lespedeza capitata....... } \\
\text { Bush clover } \\
\text { 10. Liatris punctata......... } \\
\text { Blazing star } \\
\text { 11. Oenothera latifolia........ } \\
\text { An evening primrose } \\
\text { 12. Petalostemum candidum... } \\
\text { White prairie clover } \\
\text { 13. Petalostemum purpureum. } \\
\text { Purple prairie clover } \\
\text { 14. Petalostemum villosum.... } \\
\text { Hairy prairie clover } \\
\text { 15. Psoralea tenuiflora ...... } \\
\text { Psoralea or scurfpea } \\
\text { 16. Ratibida columnifera..... } \\
\text { Prairie coneflower }\end{array}$ & $\begin{array}{l}12 \\
7-12 \\
4-5 \\
4-5 \\
8-10+ \\
10-13+ \\
4.5-5 \\
12-17 \\
7-8 \\
11-16 \\
7-9+ \\
6-7 \\
6-8 \\
4-5 \\
7-14 \\
3.5\end{array}$ & $\begin{array}{l}2 \\
1.5 \\
3 \\
1.5 \\
2.5 \\
2-3 \\
1.5 \\
1.5 \\
2.5 \\
3.5 \\
3 \\
1.5 \\
1.5 \\
2.5 \\
1-2 \\
1\end{array}$ & $\begin{array}{l}\text { M } \\
\text { PM } \\
\text { M } \\
\text { M } \\
\text { MS } \\
\text { P } \\
\text { M } \\
\text { PM } \\
\text { P } \\
\text { PM } \\
\text { MS } \\
\text { PM } \\
\text { PMS } \\
\text { S } \\
\text { PM } \\
\text { PM }\end{array}$ \\
\hline $\begin{array}{l}\text { 17. Ipomoea leptophylla.... } \\
\text { Bush morning-glory }\end{array}$ & $9-10+$ & $25+$ & $\mathrm{S}$ \\
\hline
\end{tabular}

roots, mostly horizontal in the first 5 feet, is enormous; they run off to distances of 15 to 25 feet or more.

Drawings made to scale of any of the roots of plants 1 to 16 when superimposed on that of the blazing star show great similarity in general pattern. Many of these together with photographs may be found in "The Ecological Relations of Roots" and "Root Development in the Grassland Formation" (Weaver $1919 ; 1920$ ). In none do the roots extend laterally more widely, and only those of false boneset (Kuhnia eupatorioides) penetrate deeper.

Plants of Astragalus gracilis, Glycyrrhiza lepidota and Oenothera latifolia are sometimes connected by underground parts.

Plants in this group probably absorb mostly from depths greater than those most densely occupied by the roots of grasses. At least their effect upon the grass is usually not marked except where they occur in unusually dense stands. False boneset and bush morning-glory are exceptions. Grasses beneath these plants are shaded out by the dense foliage. To occupy the soil below the grass, roots must extend deeply. In lowlands of true prairie the grass roots are coarsest, least branched, 
but deepest. Those of big bluestem (Andropogon gerardi) extend downward 7 feet. On upland prairie the grass roots are moderately fine, profusely branched, and 4 to 5.5 feet deep. Grasses of the hard lands of mixed prairie have the finest and most profusely branched roots. They are usually 4 to 5 deep (Weaver 1958).

This type of root system, which is the most common one to most of us, was found on only about one-fourth of 65 species examined. Type I occurs widely in both true prairie and plains hard lands and is often found in sandy soil.

\section{Group II}

In the second group, plants have taproots with maximum spread of abundant laterals in the surface 1 to 2 feet of soil where extensive branching provides for much absorption (Table II). Broom snakeweed (Gutierrezia sarothrae) and hairy golden aster (Chrysopsis villosa) are representative species (Figs. 2 and 3). Fringed sage (Artemisia frigida) and broom snakeweed are plants with woody bases but they are grouped here for convenience.

TABLE II. Depth and lateral spread in feet and general distribution of species found in group II

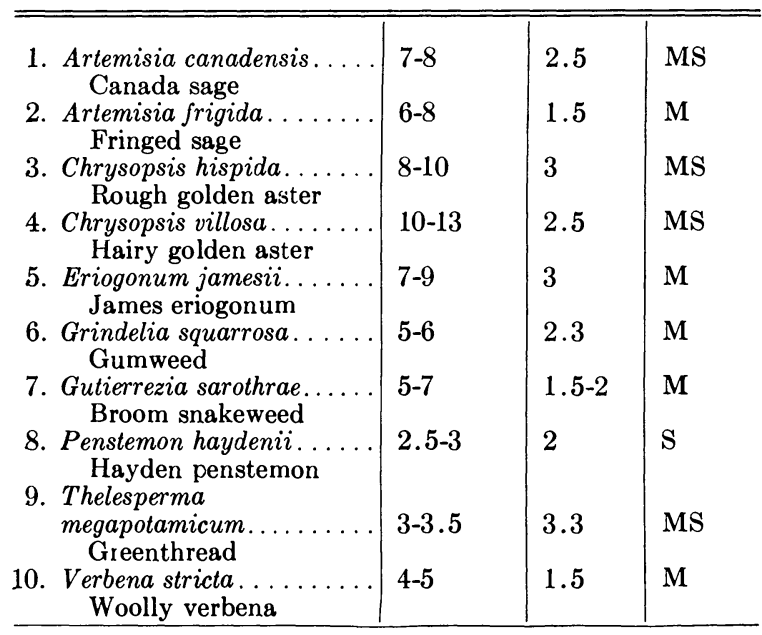

\begin{tabular}{|c|c|c|c|}
\hline \multicolumn{4}{|c|}{ Subgroup without taproots } \\
\hline 11. Opuntia comanchica..... & $2-3$ & $5-6$ & \\
\hline $\begin{array}{l}\text { 12. Tradescantia virginiana. } \\
\text { Virginia spiderwort }\end{array}$ & $1.5-2$ & 3 & SP \\
\hline $\begin{array}{l}\text { 13. Tradescantia occidentalis. } \\
\text { Prairie spiderwort }\end{array}$ & $1.5-3$ & 1.5 & SPM \\
\hline 14. Commelina virginica..... & $2-3$ & 2.3 & SPM \\
\hline $\begin{array}{l}\text { 15. Yucca glauca........ } \\
\text { Small soapweed }\end{array}$ & $6-7$ & 32 & MS \\
\hline
\end{tabular}

Only 1 of the 10 species has the great depth of penetration common to 8 species in group I. Spread of lateral roots is about the same. The chief difference is the placement of most of the

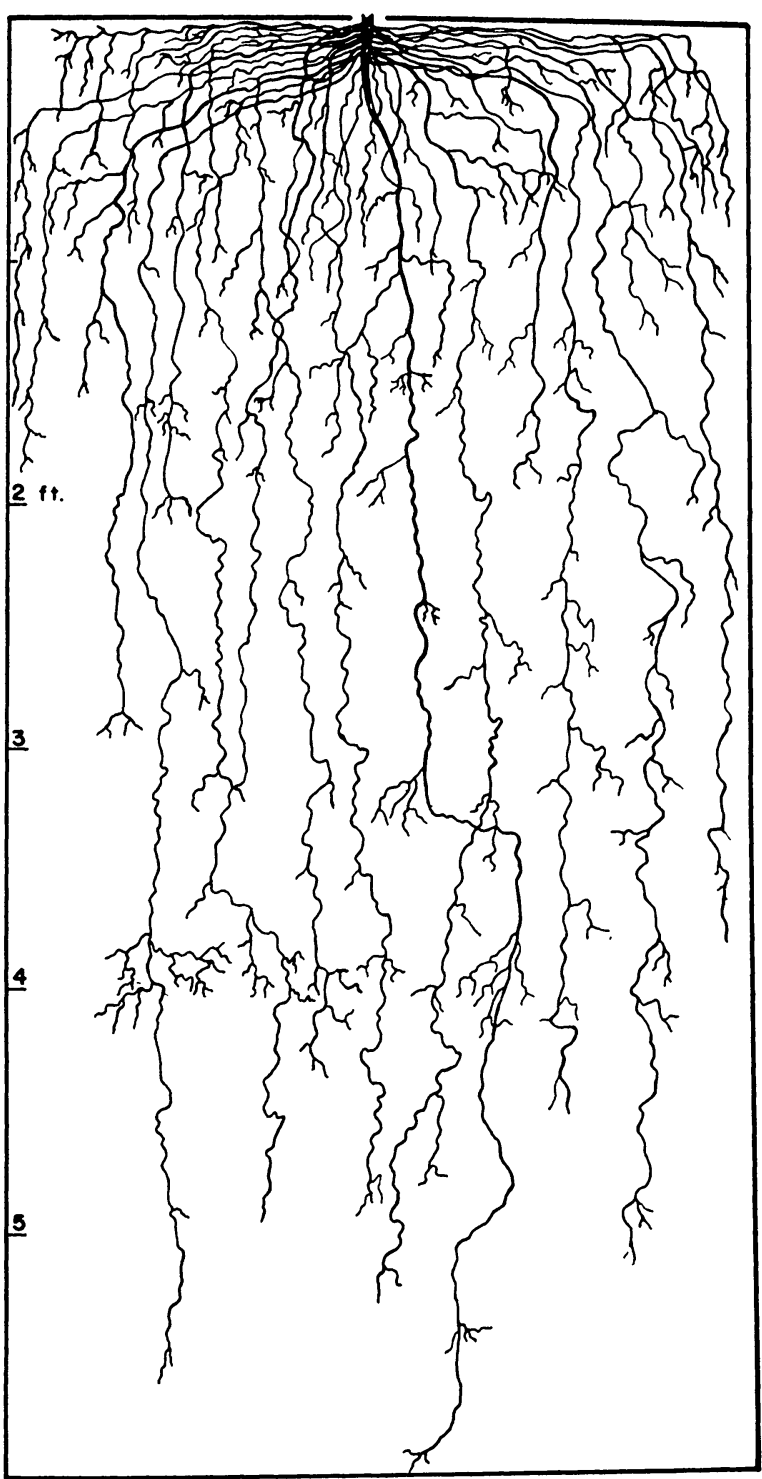

FIG. 2. Root system of broom snakeweed (Gutierrezia sarothrae). Redrawn from "The Ecological Relations of Roots."

root system in the upper portion of the soil in clirect competition with the roots of grasses and sedges.

A few species without taproots but with root systems confined largely to the surface soil where they spread very widely and compete extensively with the grasses are included in Table II. Cacti, as is well known, are among the most abundant plants of the Great Plains. Opuntia camanchica, $O$. fragilis, and $O$. polyacantha have been examined.

The root system of the first species, for example, was almost confined to the first 3 inches of soil. The widely spreading and somewhat fleshy roots furnished an enormous surface absorbing 


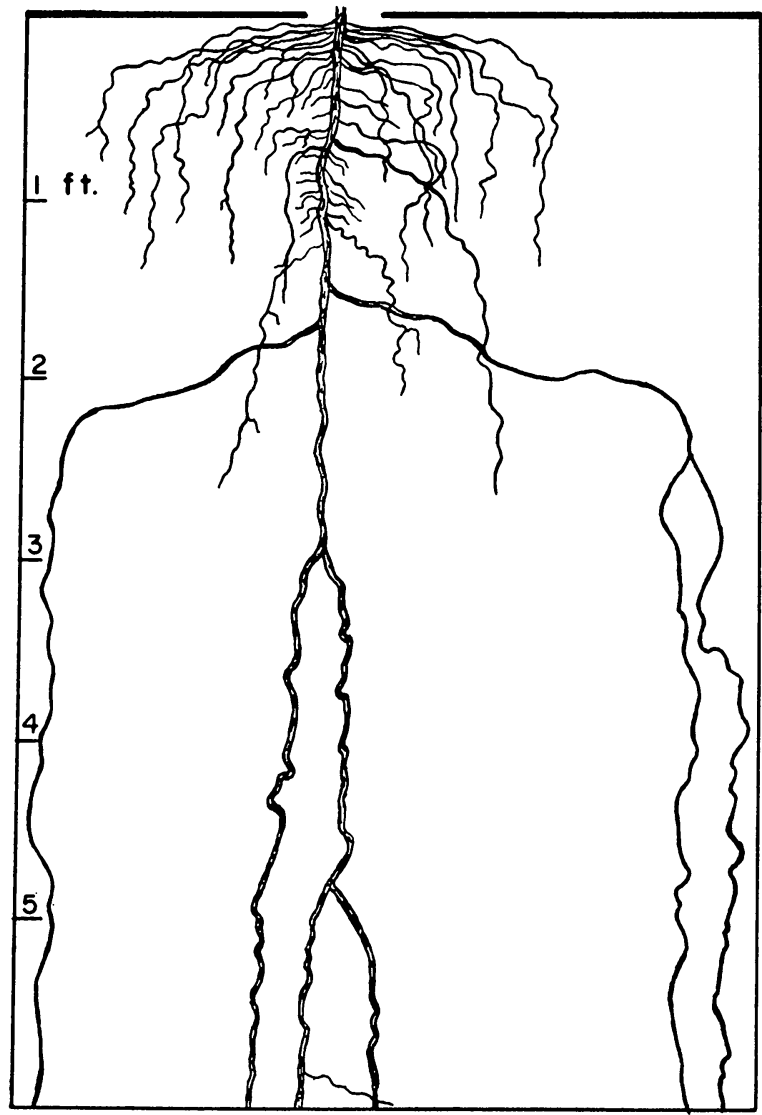

FIG. 3. Upper half of root system of hairy golden aster (Chry'sopsis villosa). The lower half had only four fine branches. Redrawn from "Ecological Relations of Roots."

system. Only 4 to 6 roots, moderately branched, extended downward and attained depths of 2 to 3 feet.

The spiderworts and dayflower, all with somewhat fleshy roots, are also so shallowly rooted that they compete for water and nutrients directly with the grasses. Small soapweed, a coarse evergreen plant, does not possess a taproot. The caudex or woody base, 3 or more inches thick, often penetrates downward 2 feet or more or extends outward or obliquely downward. From these stems arise a profusion of slender fleshy roots. These extend outward, mostly horizontally, for distances of 25 to 32 feet. Thus, roots are extremely abundant in the upper 3 feet of soil; others extend downward several feet.

The entire group of 15 species includes nearly one-fourth of the forb population under consideration. All of these occur most abundantly and many only in the hard lands and sandy soil of mixed prairie. Both species of sage become extremely abundant as the vigor of grasses declines under overuse of the range. Broom snakeweed and gumweed behave in a similar manner. Small soapweed and cacti also thicken their stand somewhat in the degree that the western ranges are overgrazed. Woolly verbena and gumweed occur only as weeds in the area occupied by true prairie.

The clay loams, silt loams, and sandy loams of the Great Plains are designated as hard land to distinguish them from sand, which is of common occurrence. These soils become so compact when dry that often a pick is necessary in making a trench for root studies. The grasses, like the forbs of this group, spread their roots widely and form dense masses in the surface soil. The very abundant deeper grass roots are also well furnished with branches. All the grasses are very drought resistant. They can undergo repeated dormancy in drought and revive again when soil water is available. The moderately fine but widely spread roots of sand-hill grasses reach depths of about 4 to 7 feet. The growth of vegetation in both true and mixed prairie occurs throughout the summer, but in sand, as on hard lands, it is somewhat according to the occurrence of rain (Weaver 1958).

\section{Group III}

A third group includes plants with taproots or several main roots which produce relatively few or no branches but penetrate deeply. When branches occur they are usually from the deeper part of the root system (Table III). Examples of the type are bractless mentzelia (Mentzelia $n u d a$ ), narrow-leaved four-o'clock (Mirabilis linearis), and pale purple coneflower (Echinacea pallida) (Fig. 4).

Plants of species numbers $2,3,6,8$, and 12

TABLE III. Depth in feet and general distribution of species in group III

\begin{tabular}{|c|c|c|}
\hline 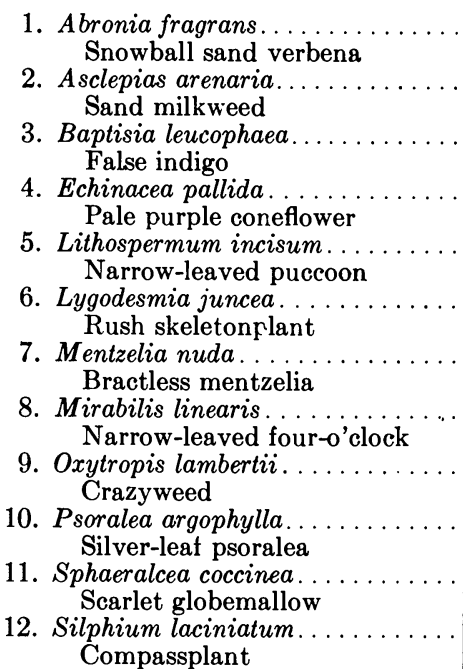 & $\begin{array}{l}3.5-4 \\
8-11 \\
7-8+ \\
6-8 \\
8-10 \\
10-21+ \\
4-5 \\
4-5.5 \\
10-12 \\
6-8 \\
8-13 \\
9-14\end{array}$ & $\begin{array}{l}\mathrm{SM} \\
\mathrm{P} \\
\mathrm{PM} \\
\mathrm{PM} \\
\mathrm{PM} \\
\mathrm{S} \\
\mathrm{M} \\
\mathrm{M} \\
\mathrm{PM} \\
\mathrm{M} \\
\mathrm{P}\end{array}$ \\
\hline
\end{tabular}




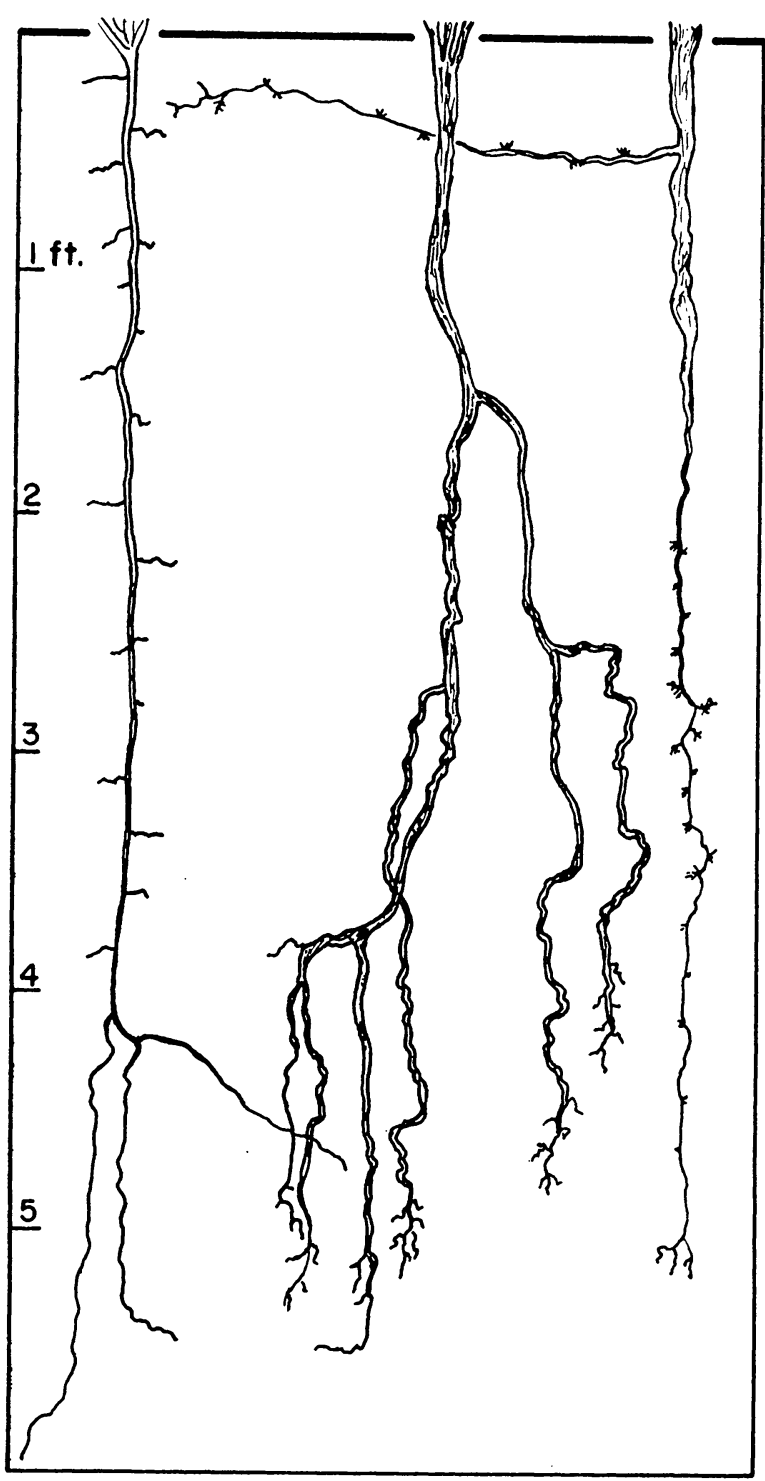

FIG. 4. Root systems of pale purple coneflower (Echinacea pallida) (left), bractless mentzelia (Mentzelia nuda) (center), and narrow-leaved four-o'clock (Mirabilis linearis) (right). Plants are from true prairie, sand hills, and plains hard lands, respectively. Redrawn from "Root Development in the Grassland Formation" and "Ecological Relations of Roots."

have fleshy roots. Those of Silphium laciniatum were of largest size, often 1 to more than 2 inches thick. This rosinweed gives rise to a few large laterals and some small ones in the deeper soil. In mixed prairie, Lygodesmia juncea sometimes produces a few unbranched laterals which closely resemble the main root.

This root type is well represented in both true and mixed prairie and somewhat less so in sand. Plants range from moderately to very deeply rooted. The 12 species in this group compose nearly 20 percent of the 65 species of forbs examined. Only two are particularly harmful to the cover of grass. These are false indigo (Baptisia leucophaea) and compassplant (Silphium laciniatum). The first has a bushy top near the soil surface which shades the grasses until midsummer, after which the stem usually breaks near the ground line and the top is blown away. Old specimens of compassplant consist of a large clump with many stems and numerous, strong, deep roots. Such plants exclude other vegetation over an area of several square feet.

Roots of plants in this group probably absorb water throughout their entire depth. The fleshy roots shrink rapidly when exposed to dry air.

\section{Group IV}

A fourth group includes forbs with rhizomes, root offshoots, or corms with numerous main roots of about equal size. Lateral spread is often indefinite (Table IV). An example is manyflowered aster (Aster ericoides) (Fig. 5).

Individual plants of lance-leaved psoralea (Pso-

TABLE IV. Depth in feet and general distribution of species in group IV

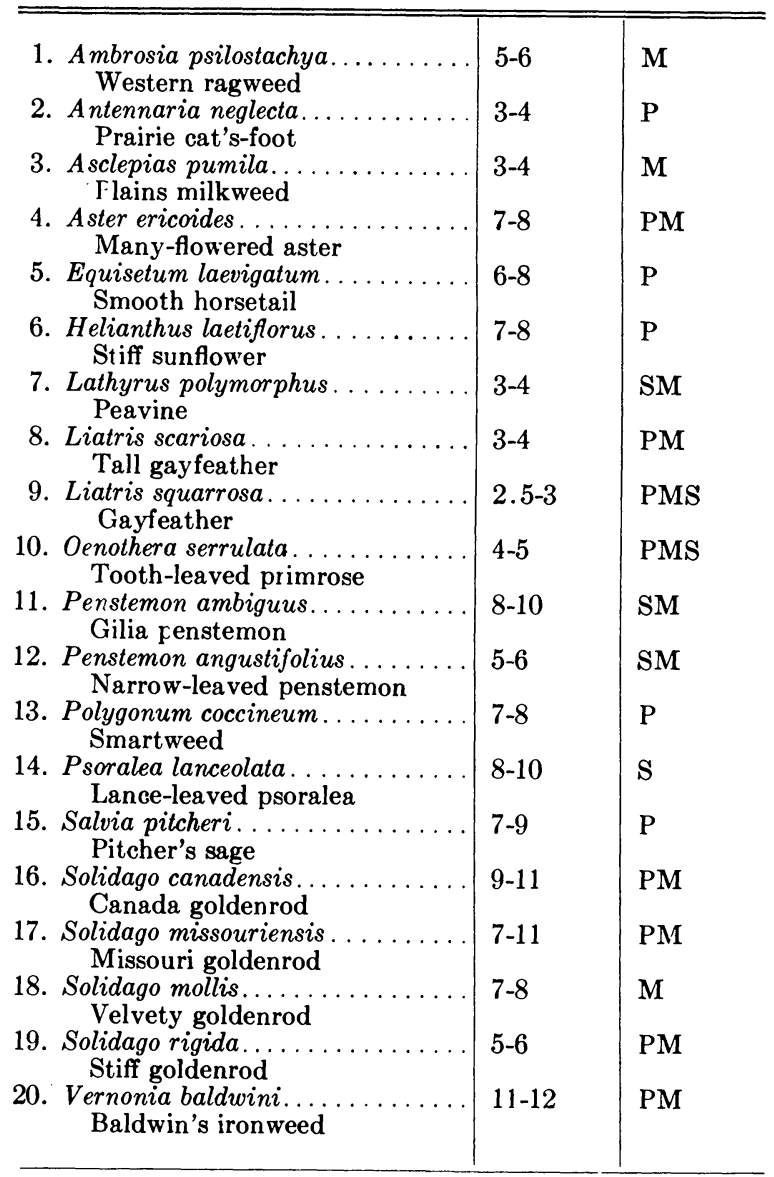




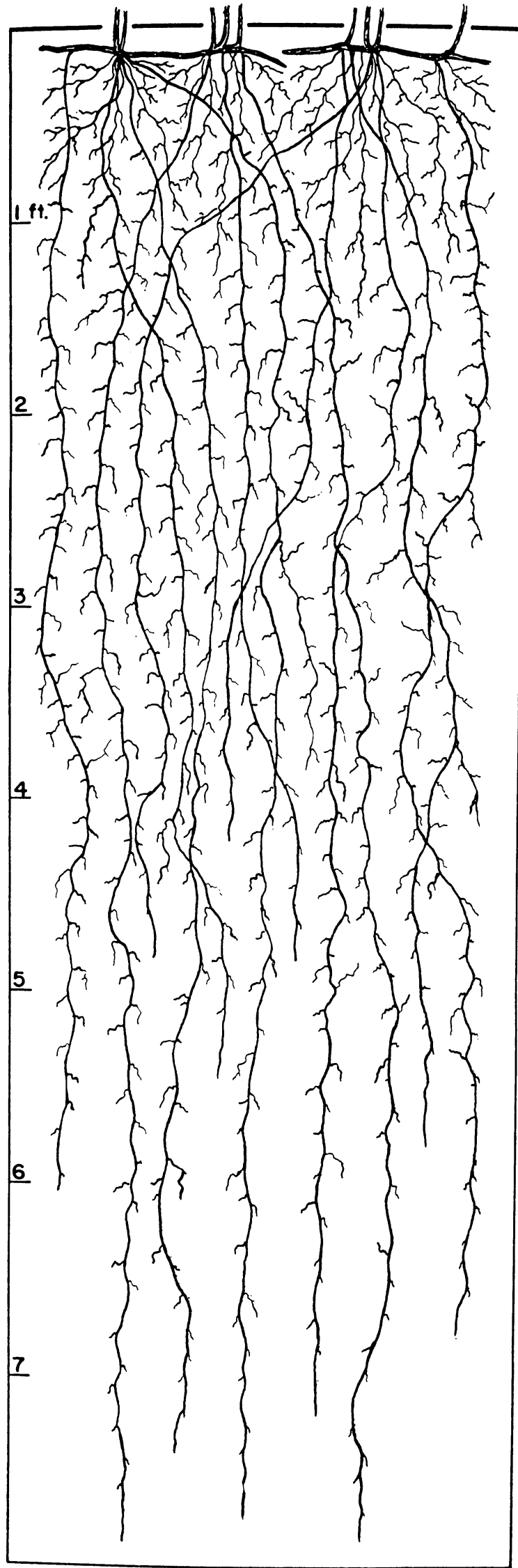

ralea lanceolata), which may be a few inches to several feet apart, are connected by a more or less horizontal system of underground parts which varies in depth from 2 inches to more than 2 feet. It may extend outward distances of 10 to more than 40 feet. At various intervals along its course new plants arise. Strong, vertically descending roots arise from these underground parts, often at some distance from the erect stems.

Many plants in this group penetrate as deeply as those with strong taproots. Others are less deeply rooted. They are about equally distributed in true prairie and mixed-prairie hard lands, with smaller numbers occurring in sand. This is the largest of the four groups and composes about 30 percent of the species examined. All absorb vigorously in the surface soil and are strong competitors of the grasses. Some of the most abundant and worst weeds in native pastures derived from true prairie are the various goldenrods, many-flowered aster, Baldwin's ironweed and western ragweed. Certain goldenrods and western ragweed are also abundant weeds of western ranges.

The root system of only one perennial forb was encountered in the grasslands that did not fit well in any of the four groups. This was Euphorbia robusta. It developed a strong taproot which extended 8 feet into the hard-land soil. No long laterals were developed. Short ones were abunlant below 2 feet to the root end.

\section{Significance of the Types in Relation to Grasses and Climate}

An examination of the four types of root systems suggests that two of these may have resulted from a long adjustment to competition with the roots of grasses. In group I there is little provision for absorption where roots of grasses are most abundant in the upper part of the solum. In group III absorption at the upper levels of the grass roots is certainly not emphasized by the unbranched or poorly branched but very deep taproots. Group IV with a general distribution of many main roots throughout the soil competes strongly with the grasses. But forbs with taproots and maximum spread of abundant and extensively branched laterals in the upper soil (group II) afford the greatest competition in dry climates. Moreover, nearly all species in this group occur in the drier western soils watered mostly by light summer rains. What are the root habits of forbs in relation to grasses in prairie with light and mostly winter rainfall? Fortu-

FIG. 5. Root system of many-flowered aster (Aster ericoides). 
nately, the root systems of many individuals of the most important species of grassland in the Pacific Northwest were examined before all of the Palouse Prairie was plowed (Weaver 1915).

The part of this grassland that was examined occurred on Northern Chernozem soil at latitude $47^{\circ} \mathrm{N}$. and at an altitude of about 2,300 feet. The mean annual precipitation is 21 inches, less than a fourth of which falls during summer. The friable, dark brown, silt loam is deep and very fertile. Both soil and subsoil are extremely retentive of moisture. This soil may be compared with a gigantic reservoir replenished during fall, winter and spring but thoroughly emptied of its water during summer. Two years of soil sampling to a depth of 6 feet substantiate this statement. In early summer the upper part of the soil loses all of its water available for plant growth, and the entire soil to a depth of 5 or more feet gradually loses most of its available supply to transpiring plants during the summer.

Several of the chief grasses, such as Idaho fescue (Festuca idahoensis), June grass (Koeleria cristata), and Sandberg bluegrass (Poa secunda), are only 12 to 28 inches tall and their roots penetrate only the upper 1.5 to 2 feet of soil. They are cool-season bunch grasses which flower early and become dormant in late June or July. In fall they renew growth, remain green during the mild winter, and develop rapidly in spring. The chief mid grass is bluebunch wheatgrass (Agropyron spicatum), also a cool-season species, and its variety inerme, now designated as $A$. inerme. Bunches of these wheatgrasses are often 10 inches in diameter, and height is about 3 feet when blossoming occurs in June. Roots do not spread widely in the surface soil, and despite the root depth of 4 to 5 feet, the plants dry early in July. Renewing growth in autumn, they remain green in winter.

In this rather dense cover of grasses, various forbs were plentiful. But with the increasing stress of drought after midsummer the landscape of dry grasses also included the leaden color of many dried, even if deeply rooted, forbs. Only a few sparsely spaced goldenrods, asters, and goldenweed continued to blossom. Late maturing species were not abundant.

Depth and spread of 12 forbs are shown in Table V. All belong to group I. There was little or no provision for much absorption in the surface foot of soil. All, except Potentilla blaschkeana, had strong taproots. It produced 2 to 5 main roots from a short thick crown.

No plant of group II, with taproot and maxi-
TABLE V. Depth and lateral spread in feet of forbs of Palouse Prairie

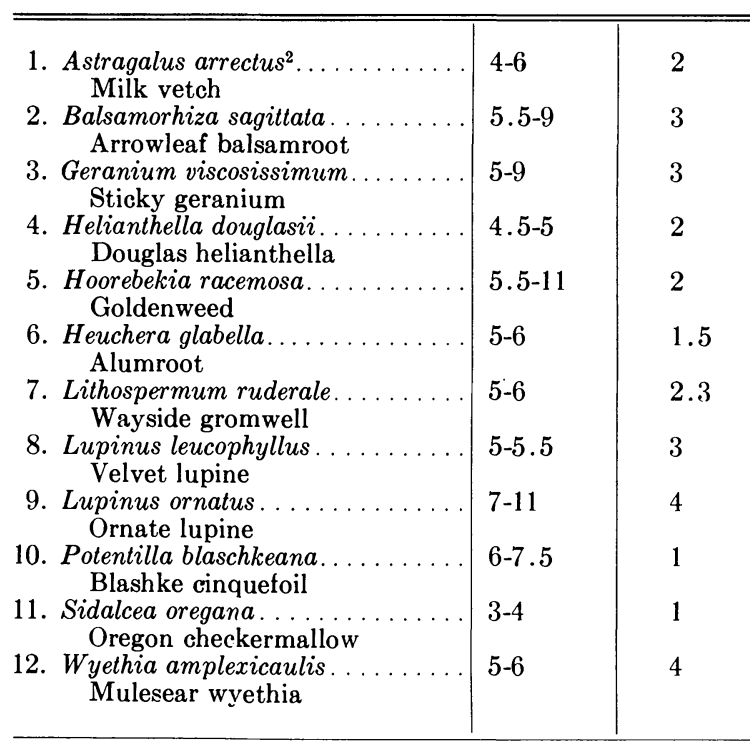

${ }^{2}$ Nomenclature follows Piper and Beattie's Flora of Southeastern Washington and Adjacent Idaho (1914).

mum spreading of branches in the surface foot, was found. Only one species, the carrot-like Leptotaenia multifida, had a fleshy taproot. It penetrated deeply (5.5 feet) and had relatively few branches (group III). Plants of two species possessed rhizomes and many small roots of about equal size which reached depths of 5 to 7.5 feet (group IV). These were Hieracium scouleri and Sieversia ciliata.

A comparison of the community root habits of vegetation under winter precipitation but similar in amount to that of parts of the Great Plains suggests the conclusion that the plains root habit of forbs in class II is a response to dry soil and light summer showers. Bouteloua gracilis, Buchloe dactyloides and Agropyron smithii, which grow both in mixed prairie and the drier parts of true prairie, develop widely spreading, shallow roots only in the plains. Moreover, there is some evidence that Grindelia squarrosa and Gutierrezia sarothrae have a more poorly developed surface absorbing system in parts of the plains with the highest rainfall. In true prairie plants seldom develop the widely spreading, superficial laterals so characteristic of many plains species. This may result from the greater and usually continuously available water content in prairie soil.

Six of the most deeply rooted plants found in this study occurred in true prairie. They were numbers $6,8,10$ and 15 of Table I and two halfshrubs, Amorpha canescens (8-17 feet) and Rosa suffulta (12-21 feet), which behave as forbs under annual mowing. 


\section{Water Supply for Deeply Rooted Species}

In true prairie the parent material below the solum, is almost continuously moist, but not wet, to many feet in depth. Deeply rooted forbs may live largely on the water that penetrates beyond the depth of the grass roots. Many of these are species of legumes. They are always interspersed among the grasses and, even where most abundant, they do not grow in such dense stands as do cultivated legumes. When Prairie soil is broken and alfalfa is grown, its taproots develop rapidly and in a few years reach depths of 30 feet or more. A two-year-old meadow in eastern Nebraska has been shown to decrease the water content to depths of 25 feet and a six-year-old one to 33 feet. The excellent growth and high yields during the first 3 or 4 years are almost independent of the amount of rainfall, since the plants are using water stored deeply. But unlike native forbs they alssorb the available water so completely that new crops of alfalfa cannot be produced on the same soil, since the deep soil is not again moistened during a very long period of years (Kiesselbach et al. 1929).

The character of the root system is usually an indicator of soil conditions. There is no substantial evidence of root penetration of plains forbs into soil where water is nonavailable for growth. It has been shown that roots of forbs do penetrate deeply even under the usual relatively light rainfall of the Great Plains (12-23 inches).

It is common knowledge among students of soils that in unusually wet years the soil of the High Plains may become wet to depths of 5 to 6 feet (Weaver and Albertson 1956, Albertson et al. 1957). Direct proof that water penetrates much deeper in places is afforded by the fact that wet soil was found in several trenches; in many instances even the deepest roots were taken from moist soil. The answer to the problem of deep water penetration under the rather light rainfall of the Great Plains seems to lie in soil disturbance.

"Ground squirrels, gophers and badgers dig and burrow deep into the earth. Harvester ants channel and loosen soil. Of scores of trenches dug in excavating roots of the prairie plants scarcely one was free from the work of recent or ancient soil excavation and refilling. Prairie dogs ranged nearly throughout the mixed prairie. They dig deeply, often to 12 or even 15 feet, and place enormous quantities of soil upon the land surface. Moreover, coarse, deep taproots upon their death and decay leave holes, curbed by soil compressed in their growth and expansion, which remain open, except perhaps at the top, a very long time.
When prolonged periods of drought occur, as they did in the early 1890's and in the recent 1930's, very deep cracks and fissures 1 to 2.5 inches wide result from the shrinking of the soil. Such periods are followed by heavy rains, little water penetrating the nearly bared and dust-covered parched soil. Large volumes of water sink through the cracks and, locally at least, thoroughly wet the deep soil. When the cracks are again closed, water is lost very slowly but permits deep root penetration" (Weaver and Albertson 1956).

soil fissures and cracks often occur at intervals of 6 to 12 feet and precipitation following extended periods of drought is sometimes three or four times the usual amount. Not infrequently the darker colored top soil was revealed in trench walls to a depth of several feet where it had been deposited in fissures by runoff water. Such differences in soils have marked effects upon root penetration and branching. When a root enters the softer soil of a filled crack or ancient burrow it usually extends much deeper and branches more profusely than other roots of the same forb or grass. In fissures differences in root depth, compared with that of surrounding vegetation, may be measured in feet. Even earthworm burrows greatly affect root extent, especially in semiarid lands. Sometimes, as in Palouse Prairie, the burrows are one-fourth inch wide and some are 10 feet in depth. Differences in soil structure at various levels in the soil profile and not uniformity is the rule in soils of the Great Plains. These result not only in variations in water content but also in nutrients. Root tubercles on native legumes are very irregularly distributed. On roots of Psoralea lanceolata, for example, branching was profuse and nodules were abundant only in the seventh to ninth foot of soil. On Amorpha canescens they occurred irregularly to a depth of 16 feet. It has been observed that in pockets of fine sand and silt abundant root branching often occurs while in adjacent layers of moist sand and gravel few or no branches are produced. Often the cause is differences in availability of nutrients.

\section{Root Habits and Response to Drought}

The response of forbs to the great drought of 1933-40 was closely related to their root habits. In midsummer of 1934 upland grasses of true prairie had wilted and dried when no available water occurred to depths of about 4 feet. This was also the fate of certain shallowly rooted forbs. Deeply rooted plants remained green and many blossomed, although somewhat earlier than usual. All types of root systems were represented, except II, in this drought-resistant group. In ravines where most lowland grasses finally lost their 
green color and were partly dried, deeply rooted forbs, although dwarfed, remained green. Thus, the persistence of forbs during the years of drought was remarkable. But with decreasing amounts of available soil moisture and extremely unfavorable aerial environment they slowly succumbed. In true prairie west of the $M$ issouri River losses were approxinately one-half to two-thirds of the forb population.

In both true and mixed prairie the more deeply rooted forbs persisted for several years. In mixed prairie only about 17 species of native perennials remained after 3 or 4 years. Excepting cactus, these were then reduced to about 10 species, none of which belonged to class II. But near the end of drought (after 1939) only Sphaeralcea coccinea, Kuhnia eupatorioides, Psoralea tenuiflora, and Cirsium undulatum could be found after prolonged searching in favored spots; the rest were seen rarely (Weaver and Albertson 1943). These plants with very deep taproots had existed on moisture available only far below the subsoil over a long period of time.

In true prairie the upper 3 to 4 feet of several forbs have been encased experimentally in such a manner that they could not absorb. During two summers the plants grew normally (Nedrow 1937). Water and probably nutrients were obtained beneath the solum. During the last years of drought a dry layer of soil, with no water available for growth, occurred between depths of 2.5 and 5 to 5.5 feet. Thus, part of the deep taproots were unable to absorb in this layer, yet many remained alive.

\section{SUMMARY}

Root systems of several plants of each of 80 species of forbs were examined and classified. Sixty-five grew among the grasses in true prairie of western Iowa and eastern Nebraska and in the hard lands or sand in mixed prairie of Kansas, Nebraska and Colorado.

The root systems were of four types. About 25 percent developed taproots with widely spreading branches which arose in the first 3 feet of soil and penetrated deeply, with little or no provision for much absorption in the surface soil (blazing star-Liatris punctata type). A second group had taproots with maximum spread of abundant laterals in the surface 1 to 2 feet where extensive branching provided for much absorption (broom snakeweed-Gutierrezia sarothrae type). With a subgroup of cacti and several monocots with similar surface-absorbing but fibrous roots, this group also composed 25 percent of the total. A third group ( pale purple coneflower-Echinacea pallida type) consisted of plants with taproots or several main roots which produced relatively few or no branches but penetrated deeply. It composed 20 percent. Forbs with rhizomes, root offshoots, or corms and with numerous main roots of about equal size (many-flowered aster-Aster multiflorus type) made up the remaining 30 percent.

There is considerable evidence that the broom snakeweed type represents an adaptation to secure water from light showers in the dry plains soil. Plants of this group were rarely found in the other prairies.

Most roots of the blazing star type absorb to great clepths, 5 to 12 or more feet, and thus below the general depth of roots of competing grasses. Twelve of 15 forbs in Palouse Prairie had this root type. Plants of the pale purple coneflower group probably compete least with the grasses for water and nutrients. When branches occur they are usually from the deepest part of the taproot. Several species have fleshy roots.

(ireat competition with grasses occurs in the many-flowered aster type. This group also produces some of the worst weeds of native pasture.

When a root system is assigned to its type, and depth and lateral spread are stated, a fair conception of its appearance may be had with little further description.

The great depth of water penetration in plains soil is considered. Root habits and response of forbs to great drought are discussed.

\section{REFERENCES}

Albertson, F. W., G. W. Tomanek and A. Riegel. 1957. Ecology of drought cycles and grazing intensity on grasslands of central Great Plains. Ecological Monog. 27: 27-44.

Kiesselbach, T. A., J. C. Russel and A. Anderson. 1929. The significance of subsoil moisture in alfalfa production. Jour. Am. Soc. Agron. 21: 241-268.

Nedrow, W. W. 1937. Studies on the ecology of roots. Ecology 18: 27-52.

Weaver, J. E. 1915. A study of the root systems of prairie plants of southeastern Washington. Plant World 18: 227-248; 273-292.

- 1919. The ecological relations of roots. Carnegie Inst. Wash. Pub. 286. 128 pp. +30 plates.

- 1920. Root development in the grassland formation. Carnegie Inst. Wash. Pub. 292. 151 pp. + 23 plates.

1958. Summary and interpretation of underground development in natural grassland communities. Ecological Monog. 28: 55-78.

and F. W. Albertson. 1943. Resurvey of grasses, forbs, and underground plant parts at the end of the great drought. Ecological Monog. 13: 63-117.

and F. W. Albertson. 1956. Grasslands of the Great Plains. Johnsen Pub. Co. Lincoln, Nebraska. 395 pp. 